CONCISE REPORT

\title{
Macrophages overloaded with tissue debris in Wegener's granulomatosis
}

\author{
Z Mackiewicz, A Rimkevičius, J Petersen, C B Andersen, E Dudek, M Vytrasova, Y T Konttinen
}

Ann Rheum Dis 2005;64:1229-1232. doi: 10.1136/ard.2004.027029

\begin{abstract}
Objectives: To analyse some scavenging related molecules in Wegener's granulomatosis (WG) macrophages.

Methods: Immunohistochemical staining of lung, nasophar$\mathrm{ynx}$, and skin for macrophage markers related to scavenging (macrophage scavenger receptor MARCO, collagenase-1 and gelatinase-B), formation of multinuclear foreign body giant cells (ADAM 9/meltrin- $\gamma$ and ADAM 12/meltrin- $\alpha$ ), and cell debris derived from neutrophils, endothelial cells and mast cells (specific granule protein 28 (SGP28), von Willebrand factor (vWF) and mast cell tryptase, respectively). TechMate staining robot and biotin-streptavidin protocol were used.

Results: Some macrophages were activated and expressed collagenase- 1 and gelatinase-B. Approximately $5 \%$ of macrophages expressed scavenger receptor, whereas 20$30 \%$ were meltrin positive. Interstitial and granuloma associated macrophages and giant cells contained partly undigested, immunoreactive SGP28-, vWF- and tryptasepositive cell rests and collagenous matrix. Lymphocytic follicles with germinal centres were found in the same areas. Conclusion: In WG tissue lesions macrophage and giant cells seem to be overwhelmed by the bulk to be scavenged. Despite cellular activation and continuing maturation to professional scavenger receptor (MARCO) and meltrin positive multinuclear giant cells combined with an organisation into granulomas, macrophages still contain partially undigested cell and tissue rests. This necrotic and damaged self may be the driving force for the formation of giant cell ("foreign body") granulomas. This, together with the local formation of secondary lymphatic follicles (with germinal centres), indicates active local antigen processing and presentation.
\end{abstract}

W egener's granulomatosis (WG) is a systemic disease of unknown origin characterised by a necrotising, granulomatous vasculitis clinically affecting the upper airways, lungs, and kidneys. Blood vessel damage is probably immunologically mediated, perhaps triggered by Staphylococcus aureus and/or endogenous proteinase 3 (PR3) autoantigen in genetically predisposed subjects. ${ }^{12}$ Some infectious conditions, especially the necrotising inflammatory processes caused by certain fungi and bacteria, can lead to granulomatous vasculitis and can be confused with Wegener's granulomatosis. ${ }^{3}$ Antineutrophil cytoplasmic autoantibodies (cANCA), primarily directed to PR3, are clinically useful markers for WG. ${ }^{4}$ Reactive oxygen species occurring in inflamed areas are important triggers of apoptosis. ${ }^{5}$ PR3ANCA induces increased adherence of neutrophils to endothelium, ${ }^{6}$ causing massive localised endothelial damage. The subsequent fate of the dead neutrophils and endothelial cells in cANCA associated vasculitis is unknown.
WG is associated with relatively massive local cell and tissue necrosis. However, it seems possible that the capacity of macrophages to act as local scavengers may not be sufficient or may be aberrant in WG. In this study we analysed several markers of local resident and immigrant cells to examine the scavenging function of macrophages.

\section{PATIENTS AND METHODS \\ Patients}

Samples were obtained from granulomatous lung tissue from three patients (Rigshospitalet, Copenhagen, Denmark) and skin and upper respiratory tract mucosa from four other patients (Red Cross Hospital, Vilnius, Lithuania). All patients had systemic WG vasculitis with lung and kidney lesions. The diagnosis was based on history, physical examination, histological findings, and laboratory tests, including PR3ANCA/cANCA. Patients from Copenhagen with lung disease had PR3 antibodies. Patients from Vilnius were not tested for PR3 antibodies as the test is not yet available. All patients fulfilled the criteria for, and definition of, WG according to the American College of Rheumatology.

Three patients with chronic obstructive pulmonary disease and two patients with non-small cell lung cancer served as comparators.

\section{Primary antibodies}

The primary antibodies used were monoclonal mouse antihuman $\mathrm{CD} 68 \operatorname{IgGl} / \mathrm{K}$ (recognising the KPl epitope) for macrophages, DAKO A/S, Glostrup, Denmark, $1 \mu \mathrm{g} / \mathrm{ml}$; rabbit antihuman macrophage receptor with collagenous structure (MARCO) IgG (a gift from Timo Pikkarainen, Karolinska Institutet, Institutionen for medicinsk biokemi och biofysik, Stockholm, Sweden) for macrophage scavenger receptor, $5 \mu \mathrm{g} / \mathrm{ml}^{7}$; monoclonal mouse antihuman matrix metalloproteinase-1 (MMP-1) IgG2a/א, CHEMICON International, Temecula, CA, USA, for collagenase-1 ("fibroblast collagenase"), $2 \mu \mathrm{g} / \mathrm{ml}$; monoclonal mouse antihuman MMP-9, IgGl/k, CHEMICON, for gelatinase B or $92 \mathrm{kDa}$ type IV collagenase, $2 \mu \mathrm{g} / \mathrm{ml}$; peptide affinity purified polyclonal rabbit antihuman ADAM 9 IgG (meltrin- $\gamma$, MDC9), Triple Point Biologics, Inc, Portland, OR, USA, $1 \mu \mathrm{g} / \mathrm{ml}$; affinity purified goat polyclonal antibody raised against a peptide mapping within an internal region of ADAM 12 (meltrin- $\alpha$ ) of human origin, Santa Cruz Biotechnology, Inc, Santa Cruz, CA, USA, $2 \mu \mathrm{g} / \mathrm{ml}$; rabbit antihuman specific granule protein 28 (SGP28)/CRISP-3, a matrix glycoprotein found in specific granules of human neutrophils (a gift from Lene Udby, Granulocyte Research Laboratory, Rigshospitalet,

Abbreviations: ADAM 9 and ADAM 12, transmembrane proteins of the zinc protease superfamily; $C A N C A$, antineutrophil cytoplasmic autoantibodies; MARCO, macrophage scavenge receptor; MCT, mast cell tryptase; MMP, matrix metalloproteinase; PR3, proteinase 3; SGP28, specific granule protein; vWF, von Willebrand factor; WG, Wegener's granulomatosis 
Copenhagen, Denmark), $1.7 \mu \mathrm{g} / \mathrm{ml}^{8}$; rabbit antihuman von Willebrand Factor (vWF), purified immunoglobulin fraction, DAKO, for endothelial cells, $1 \mu \mathrm{g} / \mathrm{ml}$; monoclonal mouse antihuman mast cell tryptase, DAKO, IgGl $/ \kappa$, for mast cells, $0.25 \mu \mathrm{g} / \mathrm{ml}$; monoclonal mouse antihuman fibroblasts IgGl/ $\kappa$, DAKO, $1.5 \mu \mathrm{g} / \mathrm{ml}$.

\section{Immunohistochemistry}

Paraffin sections $(5 \mu \mathrm{m})$ were mounted on DAKO capillary slides (TechMate, DAKO, Glostrup, Denmark), deparaffinised, processed for antigen retrieval in a microwave processing labstation (MicroMED T/T Mega Histoprocessing Labstation, Milestone Inc, Atlanta, USA), washed in phosphate buffered saline, and immunostained automatically in the robot (TechMate, DAKO) at $22^{\circ} \mathrm{C}$ using the manufacturer's protocol and kit of reagents.

Semiquantitative microscopic assessment of immunohistochemical staining was performed under $\times 400$ magnification (high power field) using four grades: $-=$ no immunoreactivity; $\pm=$ only a few immunoreactive profiles; $+=$ some immunoreactive profiles; $++=$ many immunoreactive profiles. Stained cells were counted in 10 randomly selected fields.

\section{RESULTS}

\section{General histopathology}

The lung and nasopharyngeal tissues showed necrotising and leucocytoclastic vasculitis with massive neutrophil diapedesis and tissue infiltration associated with granulomas (table 1).

In some areas no granulomas, but only remarkable mixed inflammatory perivascular cell infiltrates with small focal zones of necrosis, heavy neutrophil infiltration, and nuclear dust were present in lung and nasopharyngeal specimens.

Scattered mast cells, neutrophils, and occasional eosinophils were present. In the skin specimens no typical granulomas were found (table 1). Only necrotising vasculitis with moderate inflammatory cell infiltration and small intraepithelial vesicles were seen.

\section{Immunohistochemical findings}

CD68+ macrophages were present throughout the granulomatous inflammatory tissue (figs $1 \mathrm{~A}$ and B). Large accumulations of macrophages were always present in the lumina of alveoli. Some of the macrophages were positive for the scavenger receptor MARCO, meltrin- $\gamma$, meltrin- $\alpha$, collagenase- 1 , and gelatinase-B. About $5 \%$ of macrophages were scavenger receptor positive and $20 \%$ meltrin positive. Also, some of the blood vessels stained for meltrin- $\alpha$ (table 2 ). Intense meltrin- $\alpha$ and $-\gamma$ immunoreactivity was seen in some multinuclear giant cells. SGP28 was detected in neutrophils and in lung and tissue macrophages (figs IC and D), which sometimes was associated with engulfed but not completely digested neutrophils. vWF immunostaining was found in endothelial cells. Perivascular vWF deposits were conspicuous. vWF staining was also seen in some lung and tissue macrophages (figs IE and F). Mast cells contained apparently granular mast cell tryptase in their cytoplasm. Tryptase was also found in pericellular connective tissue matrix throughout the inflamed areas. Some macrophages also stained for mast cell tryptase (figs $\mathrm{IG}$ and $\mathrm{H}$ ), which was occasionally associated with apparently engulfed mast cell remnants in macrophages.

Strong immunoreactivity of collagenase- 1 and gelatinase B was found in almost all fibroblast-like cells in fibrotic areas. Negative control stainings confirmed the specificity of staining.

\section{Comparative samples}

In patients without WG lung tissue, cellular infiltrates consisted of neutrophils, monocytes/macrophages, lymphocytes, mast cells and, occasionally, eosinophils and plasma cells. In patients with lung carcinoma tumour cell, infiltration was present. No SGP28-, vWF- or mast cell tryptasepositive macrophages were found in these controls.

\section{DISCUSSION}

When the concept of extravascular, intra-articular immune complex disease was introduced in rheumatoid arthritis, it was noticed that rheumatoid synovial fluid contained so called rheumatoid arthritis cells, also known as rhagocytes. They were neutrophils which stained for immunoglobulin, and this despite the fact that it was well known that neutrophils themselves do not produce immunoglobulins. Later, it was shown that neutrophils isolated from rheumatoid synovial tissue also stain for immunoglobulin, probably as a result of in vivo or ex vivo phagocytosis. ${ }^{9}$ It is not known for how long phagocytosed material retains its immunoreactivity, but apparently, in a continuing process, at least long enough for even professional phagocytic and highly hydrolytic cells to stain for exogenous, phagocytosed antigens. We now demonstrate that another professional phagocyte, the macrophage, also stains for antigens apparently consisting of cell-specific markers, which are not normally produced by resting or activated macrophages. These findings are in accordance with the observations of Moosig and coworkers, for example, which suggest induction of inflammatory responses and costimulatory molecules by the uptake of apoptotic material. ${ }^{10}$

The stimulus leading to the formation of multinuclear giant cells and granulomas in WG is unknown. The observation of MARCO scavenger receptor and fusion molecules meltrin- $\alpha$ (ADAM 12) and meltrin- $\gamma$ (ADAM 9), now demonstrated for the first time in WG, suggests that for one or another reason, local tissue macrophages are driven to prefusion cells and foreign body giant cells. In the absence of any exogenous foreign bodies or evidence for microbes able to

Table 1 Histopathological findings in patients with WG

\begin{tabular}{|c|c|c|c|c|c|c|}
\hline Sample & Granuloma & Giant cells & $\begin{array}{l}\text { Necrotising } \\
\text { vasculitis }\end{array}$ & $\begin{array}{l}\text { Connective } \\
\text { tissue necrosis }\end{array}$ & $\begin{array}{l}\text { Granulation } \\
\text { tissue }\end{array}$ & $\begin{array}{l}\text { Lymphoid } \\
\text { follicles }\end{array}$ \\
\hline \multicolumn{7}{|c|}{ Patient group } \\
\hline 1 , lung & + & - & + & + & + & + \\
\hline 2 , lung & ++ & ++ & ++ & ++ & + & - \\
\hline 3 , lung & + & - & + & + & + & ++ \\
\hline 4 , skin & - & - & + & - & - & - \\
\hline 5 , skin & - & - & ++ & + & ++ & - \\
\hline 6 , skin & - & - & + & - & - & - \\
\hline $7, \operatorname{mucos}^{*}$ & + & + & + & + & + & - \\
\hline
\end{tabular}



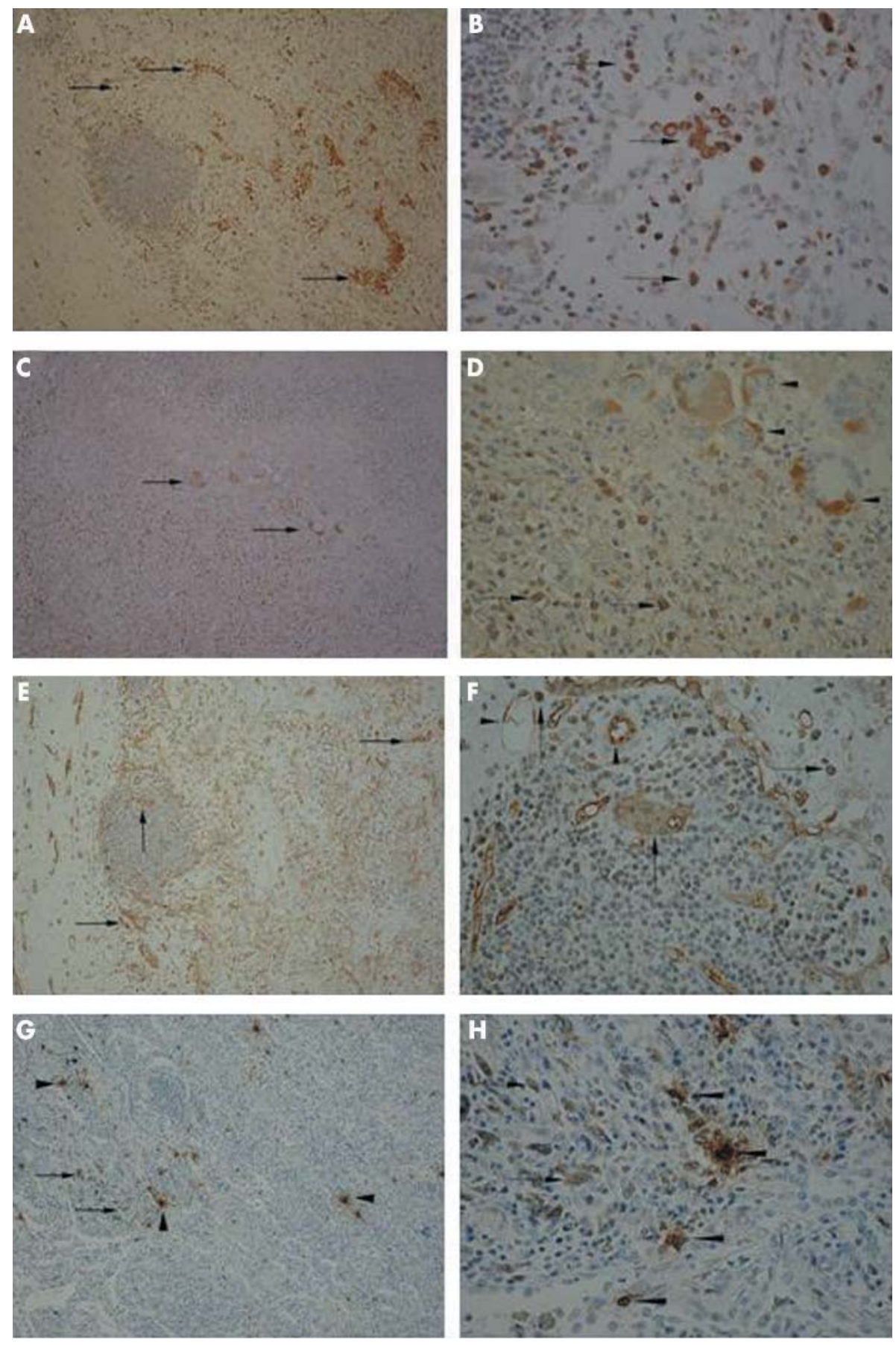

Figure 1 Immunohistochemical characteristics of scavenging macrophages in a WG lung. (A) Abundant clustered and sparse CD68+ macrophages (arrows) in WG. Original magnification $\times 100$. (B) The same, $\times 400$. (C) SGP28 positive neutrophils, multinuclear cells (arrows) and macrophages, $\times 100$. (D) The same: (multinuclear cells marked with arrowheads, neutrophils marked with arrows), $\times 400$. (E) vWF in damaged endothelial cells and macrophages (arrows), $\times 100$. (F) The same, $\times 400$. (G) Tryptase in mast cells (arrowheads) and macrophages (arrows), $\times 100$. (H) The same, $\times 400$.

induce such a response, it seems safe to conclude that the overwhelming production of endogenous tissue debris may act as an inducing stimulus. However, the specificity of the findings for WG and their relevance for the immunopathogenesis of this disease can be questioned.

Macrophages can scavenge apoptotic cells without activation of the immune response against potential antigens in such debris. In WG both local neutrophils and mast cells showed signs of degranulation and activation in the form of release of their cytoplasmic contents into extracellular space.
This leads to weak cytoplasmic staining (pale cells or "ghost cells"), combined with pericellular deposition of both SGP28 and mast cell tryptase. We conclude that the overwhelming production of endogenous cellular and tissue debris in a highly hydrolytic environment may contribute to loss of tolerance to self antigens, such as PR $3 .{ }^{11-14}$ This would be compatible with the high debris load and overfed macrophages (as observed in the present study), which were topologically colocalised with primary and secondary lymphatic follicles with germinal centres. Granulomatosis lesions 
Table 2 Immunohistochemical findings related to macrophage functions in patients with WG

\begin{tabular}{|c|c|c|c|c|c|c|c|c|c|}
\hline Sample & CD68 & MARCO* & MMP-1† & MMP-9¥ & ADAM9§ & ADAM12ף & SGP28 & vWF & MCT \\
\hline \multicolumn{10}{|c|}{ Patient group } \\
\hline 1 , lung & ++ & \pm & + & + & ++ & + & + & + & ++ \\
\hline 2 , lung & ++ & $\overline{ \pm}$ & + & - & ++ & - & - & + & ++ \\
\hline 3 , lung & ++ & \pm & - & + & ++ & + & + & ++ & ++ \\
\hline 4 , skin & ++ & \pm & - & + & + & - & + & + & ++ \\
\hline 5, skin & ++ & \pm & + & + & + & - & ++ & ++ & ++ \\
\hline 6 , skin & - & \pm & - & + & + & - & + & + & ++ \\
\hline 7, mucosa & ++ & \pm & - & + & ++ & + & + & ++ & ++ \\
\hline
\end{tabular}

${ }^{*}$ Macrophage scavenger receptor; †collagenase-1; †gelatinase-B; §meltrin- $\gamma ;$ ๑meltrin- $\alpha$

Mucosa = nasopharyngeal mucosa.

Score value: $-=$ no immunoreactivity $\pm=$ only a few immunoreactive profiles; $+=$ some immunoreactive profiles; $++=$ many immunoreactive profiles

develop in a sequential mode, leading to Thl dominated lesions in WG. ${ }^{13}$ Thus, there are differences in biopsy findings between localised and generalised forms of the disease. ${ }^{14}$

An impaired ability of macrophages to clear apoptotic neutrophils in patients with systemic lupus erythematosus has recently been described. ${ }^{15}$

\section{Authors' affiliations}

Z Mackiewicz, A Rimkevičius, Department of Pathology, Vilnius University Institute of Experimental and Clinical Medicine, Lithuania J Petersen, Laboratory of Rheumatology, The Finsen Centre, Rigshospitalet National University Hospital, Copenhagen, Denmark C B Andersen, Department of Pathology, The Laboratory Centre, Rigshospitalet National University Hospital, Copenhagen, Denmark E Dudek, Department of Cell Biology, University of Opole, Poland M Vytrasova, III. Department of Internal Medicine of Palacky University, Olomouc, Czech Republic

Y T Konttinen, Department of Medicine/invärtes medicin, Helsinki University Central Hospital, Helsinki, ORTON Orthopaedic Hospital of the Invalid Foundation, Helsinki, and COXA Hospital for the Joint Replacement, Tampere, Finland

Correspondence to: Professor Y T Konttinen, Department of Medicine/ invärtes medicin, PO Box 700 (Haartmaninkatu 8), Fl-00029 Helsinki University Hospital, Helsinki, Finland; yrjo.konttinen@helsinki.fi

Accepted 30 January 2005

\section{REFERENCES}

1 Sneller MC. Granuloma formation, implications for the pathogenesis of vasculitis. Cleve Clin J Med 2002;69(suppl 2):SII40-3.

2 Rasmussen N, Petersen J. Cellular immune responses and pathogenesis in cANCA positive vasculitides. J Autoimmun 1993;6:227-36.

3 Capizzi SA, Speks U. Does infection play a role in the pathogenesis of pulmonary vasculitis? Semin Resp Infect 2003;18:17-22.
4 Brockman H, Schwarting A, Kriegsman J, Petrow P, Gaumann A, Müller K-M, et al. Proteinase- 3 as the major autoantigen of c-ANCA is strongly expressed in lung tissue of patients with Wegener's granulomatosis. Arthritis Res 2002;4:220-5.

5 Harper L, Cockwell P, Adu D, Savage CO. Neutrophil priming and apoptosis in anti-neutrophil cytoplasmic autoantibody-associated vasculitis. Kidney Int 2001;59:1729-38.

6 Mayet WJ, Schwarting A, Meyer zum Buschenfelde KH. Cytotoxic effects of antibodies to proteinase 3 (C-ANCA) on human endothelial cells. Clin Exp Imunol 1994;97:458-65.

7 Elomaa O, Sankala M, Pikkarainen T, Bergmann U, Tuuttila A, RaatikainenAhokas $A$, et al. Structure of the human macrophage MARCO receptor and characterization of its bacteria-binding region. J Biol Chem 1998;273:4530-8.

8 Udby L, Calafat J, Sorensen OE, Borregaard N, Kjeldsen L. Identification of human cysteine-rich secretory protein 3 (CRISP-3) as a matrix protein in a subset of peroxidase-negative granules of neutrophils and in the granules of eosinophils. J Leukoc Biol 2002;72:642-9.

9 Konttinen YT, Reitamo S, Ranki A, Hayry P, Kankaanapaa U, Wegelius $O$. Characterization of the immunocompetent cells of rheumatoid synovium from sections and eluates. Arthritis Rheum 1981;24:71-9.

10 Moosig F, Csernok E, Wang G, Gross WL. Costimulatory molecules in Wegener's granulomatosis (WG): lack of expression of CD28 and preferential up-regulation of its ligands B7-1 (CD80) and B7-2 (CD86) on T cells. Clin Exp Immunol 1998;114:113-18.

11 Rarok AA, Limburg PC, Kallenberg CG. Neutrophil-activating potential of antineutrophil cytoplasm autoantibodies. J Leukoc Biol 2003;74:3-15.

12 Komocsi A, Lamprecht P, Csernok E, Mueller A, Holl-Ulrich K, Seitzer U, et al. Peripheral blood and granuloma CD4(+)CD28(-) T cells are a major source of interferon-gamma and tumor necrosis factor-alpha in Wegener's granulomatosis. Am J Pathol, 2002;160, 1717-24.

13 Muller A, Trabandt A, Gloeckner-Hofmann K, Seitzer U, Csernok E, Schonermarck $U$, et al. Localized Wegener's granulomatosis: predominance of CD26 and IFN-gamma expression. J Pathol 2000;192:113-20.

14 Lamprecht $P$, Bruhl H, Erdmann A, Holl-Ulrich K, Csernok E, Seitzer U, et al. Differences in CCR5 expression on peripheral blood CD4+CD28- T-cells and in granulomatous lesions between localized and generalized Wegener's granulomatosis. Clin Immunol 2003;108:1-7.

15 Ren Y, Tang J, Mok MY, Chan AW, Wu A, Lau CS. Increased apoptotic neutrophils and macrophages and impaired macrophage phagocytic clearance of apoptotic neutrophils in systemic lupus erythematosus. Arthritis Rheum 2003;48:2888-97. 